\title{
DEBATE COM LUIZ ANTÔNIO DE ASSIS BRASIL, MARIA AMELIA DICKIE E FABIO BARRETO SOBRE OS MUCKER
}

\author{
Daisy Macedo de Barcellos \\ Universidade Federal do Rio Grande do Sul - Brasil
}

\section{Introduç̃o}

A reunião de um escritor, uma antropóloga e um diretor de cinema já seria razão suficiente para justificar a idéia da realização desta entrevista. O interesse comum em torno de Jacobina e dos Mucker aprofunda sua importância. Ela foi projetada num encontro informal entre Carlos Steil e eu, graças a capacidade que nós acadêmicos temos de romper as fronteiras entre o trabalho e descanso. Nosso lazer e o prazer de um jantar entre amigos possibilitou o surgimento da idéia que logo a seguir foi posta em prática.

Sua concretização dependeu da concordância e da boa vontade dos autores, escolhidos que foram através do tema comum que os mobilizara na realização de seus ofícios. Agradecemos a aquiescência de Maria Amélia Dickie, antropóloga e professora do Programa de Pós-Graduação em Antropologia Social da UFSC, que gentilmente se deslocou de Florianópolis para Porto Alegre para participar da entrevista. A disponibilidade de Luiz Antônio de Assis Brasil, escritor e professor do Doutorado em Literatura da PUC/RS, que rompeu excepcionalmente seu juramento de não mais aceitar compromissos à noite e de Fábio Barreto, diretor de cinema, que concedeu parte de seu tempo de trabalho no Sul para o encontro que realizamos numa sexta-feira, dia 19 de maio deste ano de 2000, nas instalações do ILEA - Instituto Latino Americano de Estudos Superiores - no Campus do Vale da UFRGS. Dependeu também da capacidade do NAVISUAL e do Banco de Imagem de abraçarem com competência nossa proposta.

Agradeço às colegas Cornelia Eckert e Ana Luiza Carvalho da Rocha o empenho no planejamento e na organização do espaço e do equipamento necessários à gravação da entrevista; a Rafael Devos e Thaís Vieira, bolsistas de 
Iniciação Científica e de Apoio Técnico do CNPq, ambos do Banco de Imagem, que realizaram a gravação e efetuaram as cópias necessária ao processamento da transcrição e a Diego Soares e Ciana Vidor, bolsistas de Iniciação Científica que transcreveram as fitas gravadas.

Participaram como entrevistadores, interlocutores ou observadores, além de mim, Carlos Alberto Steil, Ana Luiza Carvalho Rocha, Cornélia Eckert, todos do Programa de Pós-Graduação em Antropologia Social e Isabel Cristina de Moura Carvalho, doutoranda do Programa de Pós-Graduação em Educação da UFRGS.

Nosso encontro perdurou aproximadamente duas horas. Instalados nos confortáveis sofás e poltronas da sala de reuniões do ILEA, a entrevista logo se transformou numa troca de idéias que pôde transgredir os papéis de entrevistador e entrevistado, possibilitando um diálogo aberto, embora não livre de questionamentos, sobre temas que julgávamos ser liames entre os campos de conhecimento trazidos pelos autores e suas especialidades.

Jacobina, líder dos Mucker, “Jesus renascido”, ocupou o lugar de foco em torno do qual o grupo pode fazer suas interpretações. Sua figura, por ser marcante e fugidia, possibilitou a tomada de conhecimento dos olhares que os intérpretes dos fatos que constituem a revolta dos Mucker construíram.

Visando melhor situar a problemática tratada nesta entrevista, pretendo introduzir a temática dos Mucker mediante sua breve caracterização, tomando da tese de Maria Amélia excertos que sintetizam o núcleo factual do conflito, seu tempo e seus atores. Com isso procuro situar o leitor no tema a partir do qual o debate transcorreu.

Mucker, ${ }^{1}$ "designativo cujo significado deriva de um termo antigo da língua alemã” e "qualifica uma pessoa que tem aparência de santa mas não é confiável”, ${ }^{2}$ nomeou um movimento sócio-religioso ocorrido no interior da zona de colonização alemã antiga, no Rio Grande do Sul, entre 1869 e 1874.

\footnotetext{
1 Essa designação só apareceu em documentos oficiais em 1874 embora tenha sido largamente usada para se referir ao grupo unido em torno dos Maurer. Os Mucker não deixaram registro de nenhuma autodenominação. Todas as designações eram de uma perspectiva externa ao grupo (Dickie, 1996). 2 Conforme a pesquisa de DICKIE, “o termo foi usado na Alemanha, desde o século XVI, como pejorativo para os pietistas, uma corrente 'purista' do luteranismo. Os autores que escreveram sobre os Mucker traduziram Mucker como santarrão ou beato”, o que não excluiu o sentido depreciativo (Dickie, 1996, p. 2).
} 
Eram "em torno de 150 pessoas, entre homens, mulheres e crianças, que se organizaram ao redor das interpretações da Bíblia e das mezinhas curativas de Jacobina Maurer e seu marido João Jorge Maurer, um casal de agricultores. Habitavam a região denominada Ferrabrás (linha do Ferrabrás), "uma das franjas territoriais da ex-Colônia Alemã de São Leopoldo (parte, ainda, do Município de São Leopoldo, extremo sul do Brasil). A partir desse conjunto menor, composto por 10 famílias "relacionadas entre si por vínculos de parentesco, afinidade ou parentesco ritual, desenvolveu-se ampla rede de apoio ao casal, o que pode ter envolvido cerca de 700 a 1000 pessoas, importante para uma população estimada em 14000 pessoas (Dickie, 1996, p. 1-2).

A organização do grupo em torno de Jacobina e de suas pregações, e da "aplicação" das poções curativas de seu marido, não provocou apenas a designação pejorativa. Parte dos habitantes do Ferrabrás e de outras "linhas"3 consideraram os Mucker como um problema grave para a segurança da colônia. As queixas dos colonos foram registradas oficialmente, possibilitando a abertura de um inquérito policial visando investigar a finalidade das reuniões na casa dos Maurer. Esse primeiro inquérito resultou na prisão de Maurer, que durou 45 dias, e na obrigação dele assinar um termo de compromisso de sustar as reuniões em sua casa. Jacobina foi enviada para um hospital, sob suspeita de doença mental, onde permaneceu pelo mesmo tempo.

Uma sucessão de conflitos conduziu ao agravamento do caso, já que os Maurer não cumpriram o termo assinado. O grupo ligado a eles passou a ser marcado, sofrendo perseguições e agressões às quais reagiu, configurando-se assim a chamada revolta. Os Mucker são responsabilizados pela violência que caracteriza o movimento. Assassinatos, incêndios são perpetrados, tendo sempre um "Mucker” identificado como autor e a vítima como opositora àquele grupo religioso, porém casas de Mucker são também saqueadas por seus inimigos.

Esses fatos mobilizam não apenas o poder local, mas envolveram também a província e as forças imperiais, culminando com o incêndio da casa dos Maurer

\footnotetext{
3 A expressão decorre do sistema de loteamento colonial que se dava a partir de "uma linha reta - a Linha - usada como testada para a medição de terrenos. As linhas definiram, também, a reunião de moradores para a construção de igrejas e a instalação de 'vendas' que serviam de ponto de referência para as atividades coletivas dos moradores da Linha." (Dickie, 1996, p. 1).
}

Horizontes Antropológicos, Porto Alegre, ano 6, n. 14, p. 261-300, nov. 2000 
e a prisão e a morte de muitos Mucker. Dickie informa que 17 deles sobreviveram a esse ataque, entre eles Jacobina e seus mais próximos seguidores. Estes foram posteriormente encontrados e mortos em 2 de agosto de 1874. J. J. Maurer e poucos outros não estavam entre os mortos nem foram presos.

Todos os processados (sobreviventes e mortos) foram julgados e absolvidos. Muitos dos sobreviventes não retornaram a S. Leopoldo. Instalaram-se em outras regiões e mantiveram-se unidos, casando-se entre si, morando próximos uns dos outros, por muito tempo (Dickie, 1996). Ainda no final do século XIX houve reflexos do conflito quando alguns Mucker foram mortos em represália às acusações de assassinato que pesavam sobre eles.

Os sentidos dos antagonismos atualizados através da disputa religiosa apontam para a "diferença contrastiva, assumida pelos colonos, entre si mesmos e os Mucker”. Para Dickie essa diferença não pôde ser mantida mediante regras de convivência e tolerância, mas se desenvolveu numa "animosidade conflitiva" (Dickie, 1996). As avaliações dos colonos, definidoras de quem eram os Mucker, se lidas

pelo avesso, faz ressaltar, por contraste, uma imagem de si mesmos como respeitadores das igrejas instituídas e da sua interpretação da palavra divina, bem como da moral por elas pregada. Mais ainda, como defensores de um ethos e uma visão de mundo expressos num desenho da ordem social que articulava valores como a escola, a ordem econômica, jurídica e política vigentes, a indivisibilidade e união familiares e o trabalho submetido ao calendário das igrejas e produzindo para uma circulação de bens que era a própria justificativa para a sua existência. (Dickie, 1996, p. 162).

Esses valores fundaram as diferenças que foram marcadas através da “construção do perigo". A partir dele os colonos qualificavam-se como pacíficos em oposição aos não pacíficos, onde ser pacífico significava adequar-se às normas e não sê-lo significava recusar participar delas. No caso específico dos Mucker essa recusa refletia-se, entre outras coisas, "no menosprezo pelo dinheiro e a uma relativização do valor da propriedade”, além da não freqüência de seus filhos à escola e de sua não participação junto às igrejas. Esse comportamento é mais referido nos processos do que a acusação de organização de um ataque armado, por exemplo.

A partir dos registros dos crimes imputados aos Mucker é que o perigo de 
violência passa a ser acionado, mas sempre associado a acusações referentes aos "rompimentos específicos dos Mucker com a ordem mais geral da vida, das coisas e do mundo [...]” (Dickie, 1996, p. 163). O atributo de não pacífico aplicado aos Mucker, mesmo antes de haverem fatos violentos a eles associados, falava de "uma teoria nativa" sobre a violência na qual o rompimento com o Weltanscaunng era interpretado como violência. Para os colonos ser pacífico era "estar dentro da lei”. Daí ter sido cabível situar os Mucker como perigosos para a segurança da colônia e propiciar o encaminhamento do caso às autoridades policiais.

Os colonos "acionaram a lei do Estado para sancionar atos enquadrados na sua concepção de ilegalidade, ${ }^{4}$ depois de já ter realizado e enquanto realizavam diversas agressões aos Mucker, ao mesmo tempo em que ameaçavam o Estado de 'agir por conta própria', caso ele não correspondesse às suas expectativas"5 (Dickie, 1996, p. 171, grifo da autora).

A transferência do fórum de deliberação sobre os conflitos dos controles locais para as leis do Estado redefiniu os fatos e agudizou os antagonismos. Possibilitou o reenquadramento do perigo, focando-o no risco de ações bélicas por parte dos seguidores de Jacobina, resultando em ações oficiais de repressão ao grupo e seu aniquilamento.

Em torno das interpretações destes fatos é que o presente debate se situa e é sobre as múltiplas leituras que eles possibilitam que a literatura, a antropologia e o cinema encontraram espaço de expressão.

Daisy Barcellos: Esse encontro vai proporcionar uma reflexão sobre as relações da Antropologia com a literatura e o cinema. Toma como foco um evento: os Mucker. Esse foco situa três trabalhos: um em andamento, não concluído, no caso o filme de Fábio Barreto, outro do Luiz Antônio de Assis Brasil, autor de Videiras de Cristal e o da antropóloga Maria Amélia Dickie, com a tese de

\footnotetext{
4 Atos percebidos como ilegais e que cujo controle escapava aos modos tradicionais de solução de conflitos como brigas, agressão sorrateira à propriedade como vingança, ao confronto com o adversário, num sistema em que a vitória garantia o “direito” (Dickie, 1996, p. 172).
} 
doutorado Afetos e Circunstâncias, que é um "estudo sobre os Mucker e o seu tempo".

Eu solicito que o Assis Brasil inicie, tentando dizer como, por que e de onde surgiu esse tema do romance.

Assis Brasil: Os escritores estão acostumados. Ou são os primeiros, ou os últimos a falar. Isso, de certo modo, nos coloca numa posição muito boa. $\mathrm{O}$ interesse... digamos, meu interesse pessoal, decorreu de uma circunstância muito evidente: é que vivi na colônia alemã de Estrela até os doze anos. Conheci em profundidade a alma, vamos falar assim (usar essa palavra tão ampla), do colono alemão. Meu pai era Inspetor Veterinário em Estrela, e nós éramos uma das pouquíssimas famílias luso-brasileiras naquele meio. Como dizia, era Inspetor Veterinário, e eu o acompanhava muitas vezes ao interior do município. Passei, então, a conhecer o estilo, o modo de ser, os juízos, os valores dos colonos... Eu via livros, em especial a Bíblia, na casa dos colonos alemães; vinham trazê-la com suas mãos grossas aquele livro absolutamente fascinante - porque era um livro impresso mas era um livro também manuscrito, pois as pessoas iam escrevendo as anotações dos nascimentos, casamentos e mortes da família. Realmente, era um livro raro, porque eu não podia entender como um livro impresso podia ser escrito, porque todos nós éramos proibidos de escrever nos nossos livros. Então era a Bíblia, um livro sagrado, e apesar disso, estava cheio de anotações manuscritas. Conheço bem o colono... Na minha escola, as aulas eram dadas em português, naturalmente, mas os meus colegas falavam o dialeto do Hunsrück, e eu falava junto. Depois é que melhorei um pouco as coisas, fui estudar à sério o alemão no Goethe Institut e depois passei uma temporada na Alemanha. Ademais, a minha mulher é nascida em Santa Cruz, de origem alemã, e ela é bisneta de Christian Fischer, que eu transformei em personagem no meu livro. Christian Fischer era o médico que está no livro do Petry, um homem entrevistado pelo Petry e que aparece numa foto junto com o autor. Fischer chegou durante o episódio dos Mucker em São Leopoldo, e a minha mulher chegou a conhecê-lo, já centenário. Ele possuía um problema numa perna e, mesmo assim, na comemoração do seu centenário, dançou toda a noite. Esse problema físico também recuperei na minha personagem Christian Fischer. Logo, tenho muitas razões para estar ligado na cultura alemã. E essa ligação com os Mucker vem pela recuperação desse antepassado. E mais coisas foram surgindo. Quando me dei conta, estava envolvido pela idéia. 
Maria Amélia: Bom, tem um lado afetivo e tem um lado intelectual na minha ligação com os Mucker. O lado afetivo tem a ver com toda a minha infância que foi vivida em São Leopoldo e o livro do Petry. Ele era um livro muito visível na estante de livros dos meus pais, porque ele tinha uma capinha verde que se sobressaía... assim, sempre tive curiosidade em relação a ele. Muito cedo eu o li, e desde que o li fiquei com muito medo que voltasse à acontecer algo "tão horrível” como o "episódio de Jacobina”. Mais tarde, quando eu comecei a estudar antropologia, depois de muitas reviravoltas na minha vida, meu interesse básico era sobre campesinato e sobre suas possibilidades de mobilização que, na época, eram referidas como "potencial revolucionário do campesinato". Então, o meu estudo teórico esteve muito voltado para isto, um tema em voga na década de setenta, alvo das preocupações políticas e me intrigava muito o fato de que quase todas as grandes histórias de revoluções camponesas no Brasil estavam vinculadas às questões religiosas. Ou seja, há na história grande número de líderes religiosos e não há lideres políticos. Então eu pensei, por que não investigar isso? E como eu tinha um caso tão próximo a mim, um caso que me dizia respeito tão diretamente, eu pensei bom... está o prato na mesa, vamos nos servir dele. E foi por isso que eu focalizei sobre os Mucker.

Fábio Barreto: ... Eu vou começar do Rio Grande do Sul como um estado. Um estado que sempre... , desde o meu primeiro filme, que eu vim lançar aqui, em 1982, é... eu sempre me senti muito bem aqui, sabe? Com o desenvolvimento que existe aqui, com o comportamento civilizado que existe no cidadão do Rio Grande do Sul, que é muito diferente do que a gente encontra ali no Rio de Janeiro e em São Paulo; e sempre vi as experiências, que eu tomei contato aqui, como experiências que serviriam de exemplo, vamos dizer assim, para o país como um todo. O Rio Grande do Sul como um estado que já tentou se separar do país, já tentou ser... não é? Essa região, se essa região se separasse, o Rio Grande do Sul, Paraná e Santa Catarina, seria um país fortíssimo, mais forte do que qualquer (ou alguns) países europeus. Então, sempre me deu muito prazer vir aqui. $\mathrm{O}$ meu pai sempre me contou muitas histórias daqui, porque o meu pai veio para cá na "campanha da Legalidade”, do Brizola. Ele era repórter do Cruzeiro[revista semanal de circulação nacional na década de 60] e ele veio para cá quando o Brizola deu a "entrada” ao Jango, para o Jango poder assumir. Eu sempre gostei do espírito fronteiriço do gaúcho, essa coisa assim, o patriotismo (eu vinha no carro e vinha comentando, eu vi bandeiras do 
Brasil, eu vi hoje, no avião, vi na FIERGS). Então, sabe, essa coisa que a gente hoje discute tanto, fala assim "o brasileiro tem orgulho de ser brasileiro ou não tem”, “tem vergonha de ser brasileiro”, e como é que é? Então, daí veio toda a história do $O$ Quatrilho [filme de Fábio Barreto], que me aproximou mais ainda do Rio Grande do Sul, na parte mais lá da serra, os italianos; a colônia alemã é diferente, tem um caráter mais... dizem que o alemão daqui é diferente do italiano. Já venho tendo contato com muita gente da colônia; até os próprios industriais, comerciantes, eles são mais ressabiados, mais assim... sabe! O italiano já é mais “ah vem, oh... tal... como é que é ?” Me pegavam durante o filme, agarravam a minha mão e falavam assim: "O que você esta sentindo, você está sentindo o quê!?” Os alemães já são mais cuidadosos, mais... estudam... , mais cautelosos, precavidos... não é? Mas basicamente, veio do Horst Volk, um industrial (dono da Ortopé), que no Festival [festival de cinema] de Gramado de 1995 deu um almoço lá, em homenagem à gente e me deu o livro para ler, me deu Videiras de Cristal - olha, isso aqui dá um filme. Achei uma maravilha. Eu já conhecia o filme do Jorge Bodanski [Os Mucker], que eu tinha achado, na época, interessantíssimo. É um belo filme e fiquei muito interessado. Entramos em contato com o Assis Brasil e tal e, me interessou também porque a proximidade, quer dizer, a minha atração pelo tema, no caso, vem da questão da espiritualidade do ser humano. A partir, também, desse momento, a minha vida começou a ter... , eu comecei a abri-la mais para essa questão da espiritualidade, na minha própria vida. Uma investigação interior minha, o que isso significa para mim, o contato que eu tenho com isso. Eu sempre fui uma pessoa que nunca tive apego a nenhuma religião. Já me chamei de ateu, numa época... Apesar de ter tido uma formação católica. Mas o meu pai era comunista, foi comunista. Mas ele dizia (sei lá) você tem que ir à igreja, você tem que fazer a primeira comunhão senão na escola vão te chamar de pagão. Você tem que fazer isso, você tem que ir lá, tem que fazer... vai ser batizado, mas nunca ele me deu uma formação religiosa, nem minha mãe, apesar dos meus avós serem religiosos. Mas eu tive [contato]. Não era de ir no domingo à igreja, mas de vez em quando ia. Achava interessante, às vezes chato. A religião sempre esteve ligada a uma coisa meio chata para mim. A aula de catecismo no colégio era chata, quer dizer, não era uma coisa que me interessava. Nunca tive muito o hábito de rezar. Isso é uma coisa que eu adquiri recentemente. Recentemente é que eu estou mais... Eu me atraía mais, vamos dizer mesmo, pelo marxismo, pelo materialismo... sabe!? Apesar de ter um homem que era muito inte- 
ressante, que foi... era pai da minha ex-mulher, um psicanalista chamado Hélio Pellegrino que... ele falava muito dessa questão do socialismo e da religião. Ele era um homem religioso, falava muito de Deus. E isso me despertou, numa época, para essa questão, sendo que dentro do romance do Assis Brasil, o que mais me interessou e me fisgou mesmo, na personagem da Jacobina, é essa questão do espírito e do corpo. Como que essa dualidade que pertence a todo e qualquer ser humano, poderia vir a ser explorada nesse assunto. Principalmente, levando-se em conta o comportamento da Jacobina na história toda. Como que ela lidava com isso. Que tipo de conflitos isso proporcionava nela, que tipo de contradição. Então é mais ou menos nessa linha que vou, que estou tentando conduzir o filme e o roteiro do filme.

Daisy Barcellos: Maria Amélia fala de mobilização política e toma a questão religiosa como um dos modos de ver como os movimentos políticos e sociais estão, na nossa sociedade, articulados, em vários deles, com esse potencial de religiosidade. Canudos é um exemplo importante e também suscitou leituras múltiplas. Fábio aponta também a questão da espiritualidade, essa dualidade e essa contradição, e focaliza em Jacobina. Quem é Jacobina?

Fábio Barreto: Eu queria fazer um aparte aqui. Canudos, eu acho que teve uma característica política bem mais marcada, na medida que o líder do movimento, o Antônio Conselheiro, ele era um anti-republicano declarado, ele pregava à volta à monarquia mesmo, para valer, era um movimento marcadamente político, tinha essa intenção, ele meio que queria derrubar a República e voltar a monarquia. Não sei se derrubar, mas pelo menos fazer campanha, fazer discursos e tal. Que é uma coisa que é diferente dos Mucker, no caso.

Daisy Barcellos: Apenas refiro a relação entre o apelo religioso e a capacidade de mobilização de uma comunidade em torno de uma liderança.

Carlos Steil: Penso que esses dois movimentos têm em comum é o milenarismo, embora sejam de origens diversas. O milenarismo da Jacobina, dos Mucker, é um milenarismo protestante. Além disso, a própria Jacobina tinha antepassados que pertenceram a um movimento milenarista.

Assis Brasil: ... sim, anabatistas... 
Carlos Steil: ... o avô dela foi milenarista...

Assis Brasil: ... Mentz...

Carlos Steil: ... O milenarismo de Canudos, do Antônio Conselheiro, era um milenarismo sebastianista, como o Assis Brasil bem lembrou. Um milenarismo que teve uma inserção e enraizamento no Nordeste. Temos aí um outro contexto que com as pregações do Vieira ganhou uma conotação muito própria, muito nacional inclusive. Um milenarismo que se torna uma utopia realizada. A outra questão que gostaríamos de retomar refere-se à espiritualidade da Jacobina que, assim como ao Fábio, também me impressionou no romance, e que também é ressaltada pela Maria Amélia. Uma espiritualidade que ainda hoje causa um impacto, como a Maria Amélia relata no artigo publicado em Horizontes Antropológicos. Um artigo seu muito interessante porque mostra a Jacobina identificada como bruxa num contexto moderno de Nova Era. Mas, ela mesma pode falar melhor do que eu, como isso aconteceu. Apresentando a Jacobina num congresso internacional, uma pessoa levanta e diz - Eu sou irmã da Jacobina. - Como? Você é irmã da Jacobina? - Assim como ela, eu também sou bruxa. Então, é uma história que dá atualidade a Jacobina. A atualidade dos Mucker, ou a atualidade da Jacobina, é algo que nós gostaríamos que vocês explorassem um pouco mais. Pois trata-se de um acontecimento que transcende o tempo e a região, e pode ser pensado como um episódio que vai para além do século XIX, e para além da colônia alemã no Rio Grande do Sul.

Assis Brasil: Sim, porque trata de universais, aí é que está a questão. É essa oposição entre de corpo e alma, pecado e virtude... é um tema que percorre o pensamento, especialmente o pensamento ocidental, há milênios... Sempre será atual. No caso dos Mucker, eu conhecia o colono, e sabia o quanto era ordeiro, disciplinado, trabalhador, obediente. Presenciei cenas patéticas. Meu pai, como veterinário da Secretaria da Agricultura, estava revestido de autoridade sanitária, com poder de vida e morte sobre os animais. E recordo perfeitamente de um momento em que ele, após examinar os animais de um colono e disse: "Tu tens de abater esta vaca”. O colono não perguntou nada, só disse: "Sim senhor!” Meu pai então determinou : "Depois tens que queimar a vaca e enterrar, se não vai contaminar todo o teu rebanho”. O colono não estava acreditando naquilo, isto é, não acreditava muito que a vaca estava com uma doença que 
iria transmitir aos outros animais. E mesmo assim obedeceu, de cabeça baixa. Quando eu pensava na questão Mucker eu me perguntava "mas como eles acabaram se envolvendo num episódio de drama, sangue e paixão”? Talvez a escrita desse romance tenha sido uma tentativa de entender um pouco isso, como é que chegaram a esse ponto, por que o episódio assumiu contornos absolutamente dramáticos e sanguinários em algumas circunstâncias...

Fábio Barreto: Trágicos...

Assis Brasil: Trágicos... Houve incêndios. Queima de famílias. Percebo que havia uma espécie de uma capa protetora dos sentimentos, da emoção, da paixão, da carne. Quando tudo emergiu, não houve como controlar. Tudo isso decorreu de uma de cultura muito repressiva. Por outro lado, também há algo muito interessante a anotar: considero os Mucker um episódio original. A originalidade centra-se no seguinte: na colônia alemã havia católicos e protestante luteranos, mas mais protestantes que católicos. Estavam acostumados a uma espécie de um sagrado masculino, sem nenhum espaço para a Virgem Maria, [existente] para os católicos. Os Mucker portanto vêm instituir uma espécie de um sagrado feminino na figura dessa mulher, e isso é absolutamente fascinante. É um ponto de visão que a mim me seduziu muito, e por isso eu fiz essa personagem como ela é. Claro, fiz à minha maneira, mas tentando preservar o lado feminino da sedução. Minha personagem beija na boca os homens que estão ali, não apenas o seu marido. Quer dizer: há um cruzamento entre sagrado e feminino, via incesto, o que acho muito interessante e significativo; de certo modo explica muito dos fatos que aconteceram lá.

Carlos Steil: Entendendo o Videiras de Cristal e agora com a entrevista, [os Mucker] é uma transgressão de cima a baixo, não é?

Assis Brasil: É claro que sim!

Carlos Steil: Eu conversava com a Daisy, que esta transgressão de gênero, parece que ela permite todas as outras transgressões: de hierarquia, no conflito entre o pastor ordenado e o não ordenado, em relação às crianças, na proibição de freqüentarem a escola, das relações no casamento, na insinuação do amor livre da Jacobina. 
Daisy Barcellos: ... e com isso ela transgride muitas outras ordens, desde a ordem médica à ordem jurídica. Ela transgride todos os acordos e normas daquele tempo, não é?

Assis Brasil: Pelo menos no imaginário é isso que ficou. E é isso que importa na verdade. É claro, o interdito erótico era muito forte também. Então a transgressão se tornou mais dramática. Especialmente no caso, ali, em que ela trilhava esse contexto sagrado.

Fábio Barreto: Eu gostaria de ouvir um pouco essa história da bruxa. Como foi essa história, até para gente associar isso ao sagrado feminino?

Maria Amélia: Antes de falar da bruxa, eu só queria dizer uma coisa a respeito do foco na Jacobina. Relendo "Videiras de Cristal" esta semana, eu tive a nítida sensação que, sinceramente, toda a tua motivação era porque tu tinhas sido absolutamente seduzido pela Jacobina.

Assis Brasil: Ah, claro...

Maria Amélia: ... e não só isso, como tu tinhas permeado o teu livro inteiro com personagens que eram fragmentos da Jacobina. Todos os personagens femininos são personagens que postos juntos, eles desembocam na Jacobina. E achei isso fascinante porque da primeira vez eu não tinha notado. Então eu acho que além da espiritualidade, talvez muito mais importante do que a espiritualidade é toda a sensualidade que a Jacobina foi impedida de exercer pelo ambiente dominante e que ela então conseguiu criar espaço dela, para fazer isso, para exercer essa sensualidade, e o modo como ela entendia, como ela gostava. A história da bruxa é o seguinte. Foi muito impactante para mim. Eu tinha recém terminado de escrever a tese, estava na Inglaterra, em uma "vetusta” instituição inglesa, apresentando o meu trabalho num seminário. E várias pessoas que tinham ido lá não sabiam que era eu quem iria falar, estavam meio chateadas porque estavam na expectativa de ver outra pessoa falando e de repente aparece alguém falando dos alemães lá do Sul do Brasil. E eu notava que as pessoas estavam um pouco incômodas mas, aos poucos, esse pessoal foi mudando e no final uma mulher, uma mulher absolutamente comum que estava no fundo da mesa, se aproximou de mim e começou a conversar 
sobre a questão das crianças não serem educadas em escolas que eu tinha mencionado no caso dos Mucker: que Jacobina tinha mandado retirar as crianças da escola. Ela disse, "pois é ... aqui na Inglaterra, tem um movimento forte de pais que querem deixar os filhos em casa. Eu participo deste movimento"; é institucionalizado, como toda boa coisa inglesa, então [disse], "eu sou deste movimento”. Ficamos conversando. Do seminário... a gente ía parar em um $p u b$ - a gente estava atravessando uma rua fantasticamente imensa de Londres - e eu notei que o nome dela não era inglês e perguntei de onde era. Ela disse que era galesa, que vinha a Londres periodicamente para ir a este seminário, nesta instituição onde eu estava e também para o seu templo. Quando ela me disse templo, claro que eu tive que perguntar, bom, qual é a sua religião? "Eu sou bruxa”. E continuou atravessando a rua. Eu levei um susto porque não esperava encontrar uma bruxa galesa numa instituição como aquela. Fomos conversando, e no pub, então, ela foi me contando coisas sobre ela. E, à medida que ela ia contando as coisas sobre ela, eu notava que ia aumentando o nível de segredo do que estava me revelando. Ou seja, ela estava me deixando entrar mais. E até num dado momento eu perguntei por que ela estava se abrindo tanto e ela me disse, "bem, porque Jacobina é minha irmã. Eu sei quem é esta mulher, eu sou ela. Então, tudo o que você falou, não era surpresa para mim, eu conheço. Isto que você falou, eu conheço, eu sei”. E para mim foi muito bom, porque quando ela disse isto eu me dei conta de que Jacobina não era Jacobina, era uma mulher absolutamente universal. E portanto, ela me possibilitou ver as Jacobinas que eu não tinha visto, a partir da história dela. O artigo é mais ou menos sobre isto.

Fábio Barreto: Engraçado, estava tentando juntar as coisas, bruxaria com o sagrado feminino, para chegar na barbárie mesmo que virou a coisa...

Maria Amélia:... mas por quê?

Fábio Barreto: ... que isto me fascinou? Porque chegou ao ponto que chegou. Aos incêndios, a matar crianças. Aquela coisa toda... que é uma dificuldade que eu estou lidando no meu roteiro. Você entendeu? No que eu apresento este tipo de coisa para produtores, eles lêem aquilo e dizem não, isto aqui não tem... Sabe? As pessoas vão para o cinema e não vão querer assistir isto. (risos) Não vou meter dinheiro num negócio que as pessoas não vão querer ver. Você 
entendeu? É uma dificuldade para mim. Eles acham que não tem justificativa, que eu não consigo... entendeu? Suprime, tira, não pode. Quem vai gostar desta mulher se ela manda matar os outros desse jeito, se ela está de acordo com isto? Você entendeu?

Maria Amélia: O que é interessante no paralelo com a bruxa é porque esta bruxa contemporânea, na Inglaterra, sofre os mesmos tipos de repressões e de preconceitos que Jacobina sofreu. É, exatamente os mesmos. Ela é reprimida nos mesmos planos que a Jacobina foi reprimida.

Fábio Barreto: ... da sensualidade inclusive?

Maria Amélia: E é atribuído a ela o rapto de crianças. Ela é investigada pela Scotland Yard como tendo raptado crianças para usá-las para sexo ilícito. Aí a Scotland Yard, muito eficiente, prova que ela é inocente. Ela é inocente mas ela foi acusada, foi investigada, houve um dispêndio de dinheiro... depois saiu no jornal declarando quanto eles tinham gasto investigando, porque isto na Inglaterra é importante. Mas quero te dizer que esta mulher tinha as vias institucionais, digamos assim, para reagir. Ela foi a advogado. Eu acho que no caso da Jacobina e daqueles colonos, a primeira tentativa dela não tinha nada a ver com esta violência que se desencadeou. A violência é resultado de um processo de interação com um mundo absolutamente hostil. E hostil à possibilidade da divindade estar presente numa mulher. Eu acho que este é um possível desencadeador de toda violência, não é? E é assim por parte dos jesuítas que estavam absolutamente histéricos com o fato de que ela não estava vendo a Virgem Maria e não era personificação de Virgem Maria no mundo. Ela se recusava a esta associação, inclusive ela foi explicitamente contrária, ela recusou direto! Os luteranos estavam estarrecidos sem saber como interpretar isto. E, claro, os intelectuais dizendo que era crendice dos jesuítas, das coisas que botaram na cabeça dos colonos, então, a reação foi crescendo, mas é uma reação contextual, totalmente contextual. Ela não era louca, não era desvairada, era simplesmente ela e os amigos dela...

Fábio Barreto: Uma fanática?

Maria Amélia: De jeito nenhum, ela estava defendendo o que era dela, seu bem mais precioso que era a sua comunicação com Deus. Era o seu bem, era 
ela, era sua individualidade associada a dos seus asseclas (esta não é uma boa palavra para definir os seus amigos); era isto que estavam defendendo. Eles todos estavam defendendo um valor muito maior que qualquer dos outros que estavam sendo defendidos pelos opositores por causa dela.

Carlos Steil: Acho que vocês poderiam retomar a questão da sexualidade como um campo de expressão do carisma da Jacobina. Como é que vocês vêem isso, como trabalharam no romance e na tese, ou como o Fábio pretende trabalhar no filme?

Fábio Barreto: Acho que o poder de atuação está ligado a esta coisa que o Assis localizou, do sagrado feminino. Ali, naquela comunidade, naquele grupo, criou-se uma coisa que normalmente não se cria em grupo nenhum, não é? Uma permissividade. Esta mulher tinha alguma coisa especial então, ela podia transgredir. A transgressão era permitida. E essa transgressão chegou ao crime. Porque virou crime, não é?

Maria Amélia: Para as autoridades brasileiras. Para ela [Jacobina] não era crime. Para ela era o que tinha que ser feito.

Fábio Barreto: Ela estava se defendendo, mas criminosamente. Não só pela autoridade brasileira, mas que é uma pessoa que manda, que mata, não ela [Jacobina] com as próprias mãos, mas que está de acordo, que é cúmplice daquilo, é uma criminosa, não é? Ela é. Com aqueles atentados todos que tem, botar fogo nas casas das famílias, as crianças, etc.

Maria Amélia: Engraçado que não há registros sobre os crimes contra os Mucker. Porque eles existem. Os Mucker foram atacados antes. Nesse sentido foi um revide. Interessante, a tua versão, simplificada, é a versão que todo mundo enxerga "eles são os criminosos". Assim, a Jacobina aparece como a criminosa, a mandante de atrocidades, de graça...

Assis Brasil: Podes estar assumindo, por uma questão dialética, a posição...

Fábio Barreto: ... do advogado do diabo. 
Maria Amélia: Então, claro. Mas exatamente, digo isso, no drama do teu filme, sobre quem é a Jacobina, estou vendo um fio, um meio de como explicar esta mulher. Bom, eu acho que uma das formas é mostrar que o outro lado é tão sedutor, tão violento quanto. Ela na verdade se defendeu, ela reagiu à forma como estava sendo agredida.

Daisy Barcellos: E com as regras do jogo.

Maria Amélia: Com as regras daquele jogo. Era uma guerra...

Fábio Barreto: E, até certo ponto, eu acho que ela perdeu o controle disso, não é?

Assis Brasil: Sim, no final.

Fábio Barreto: Acho que ela não tinha mais conhecimento até do grau das coisas que estavam ocorrendo. Nem eram mandadas, nem eram orientadas por ela. Vamos lá, acaba com aquela família, toca fogo naquilo lá, mata todo mundo...

Assis Brasil: Acredito que muitas das ações lhe escaparam, como é natural; mas isso acontece quase sempre quando há estes movimentos coletivos: os líderes acabam prisioneiros do próprio movimento que criaram...

Carlos Steil: Do próprio carisma.

Assis Brasil: Exatamente. Aquele papel tem de ser levado até o fim.

Fábio Barreto: Estive vendo uns episódios que aconteceram recentemente, de seitas, você entendeu, teve um nos Estados Unidos, tudo parte das coisas de criança, a coisa da sexualidade, você entendeu? Tudo vai bater no mesmo lugar.

Assis Brasil: É claro, o caso Jim Jones

Carlos Steil: e agora este, mais recente, na África... 
Assis Brasil: É claro, mais recente ainda, quase $300 \ldots$

Carlos Steil: ... os jornais falam de mais de mil pessoas.

Assis Brasil: E que é perfeitamente possível. Agora, a questão toda é como isto aconteceu aqui e nesta comunidade.

Daisy Barcellos: Uma comunidade teuto-brasileira.

Assis Brasil: Isto é que deixa, então, a coisa mais instigante. Quando eu lia o que havia publicado até então sobre os Mucker, não fechava com o colono que eu conhecia.

Ana Luiza Rocha: A Maria Amélia tocou numa questão que eu acho importante. Não seria interessante fazer também aqui uma referência ao contexto da cultura alemã e da sociedade brasileira na época dos episódios aqui citados? Existe também uma mitologia criada fora disso, do próprio evento acontecido que complexifica o próprio ato de interpretação. Então, acredito que há outras variáveis que estão aí dentro dos próprios fatos ocorridos e registrados pela História que contaminam o olhar do escritor, do cineasta e do próprio antropólogo. Como é que vocês trabalharam isto nas suas áreas de produção? No caso do romance [a Assis Brasil], ou no teu caso [a Maria Amélia], como antropóloga, como é que vocês vivem esses constrangimentos nas suas produções intelectuais? Ou seja, há sempre uma interpretação, e isto remete à discussão do processo de relativização em Antropologia, do estranhamento, da busca de objetividade. Nós estamos atravessados de imagens deste evento que estão para além dele...

Daisy Barcellos: E todos vocês já trabalhando com interpretações, pois trabalham sobre textos e documentos.

Assis Brasil: O caso é o seguinte: sempre foi considerado um mau episódio. Tem-se de partir disso. Um mau episódio. Não deveria ter acontecido.

Maria Amélia: É uma “grande vergonha”. 
Assis Brasil: É claro, esta é a grande vergonha. Não podia acontecer, e por todas as razões. Especialmente por ser uma comunidade com todos esses valores. E aconteceu num meio tão “bom”, quer dizer, os brasileiros são considerados tão "amáveis”... E como aconteceu? Quem permitiu que isso tivesse acontecido? Essa questão ainda não está resolvida. No meu olhar, embora ele tenha muito de interrogação, “como isto pôde acontecer?” subjaz uma afirmação: “mas não devia ter acontecido... ”. É essa a verdadeira questão. Por mais que eu queira colocar a coisa em parâmetros, até certo ponto lógicos...

Fábio Barreto: “Fechado”...

Assis Brasil: É. Enfim, existe um pouco esta coisa: por quê? Não era desconhecido da minha infância o episódio dos Mucker. Fiquei sabendo porque dele se falava, lá em Estrela. Inclusive, se falava que havia um Mucker por lá, que ninguém sabia quem era. Tudo um mistério. Fico pensando, agora, que muitas coisas podem mudar contemporaneamente, depois do romance, da tese, do filme. Quero relatar um episódio que acho muito significativo. Depois de um ano da publicação do Videiras de Cristal - que foi um livro que imediatamente teve uma larga venda por razões que eu sei que são razões extraliterárias houve um seminário promovido pela Universidade Federal de Santa Maria sobre a obra. Dei meu depoimento ao final do evento. Quando terminei, vieram várias pessoas me cumprimentar. E um senhor veio, e em particular me relatou: "Como o senhor vê, não sou um homem jovem (uns 60 anos). Gostei muito do seu livro”. “Ah, bem, tudo bem... desculpe, mas como é o seu nome? - e aí ele me disse o nome exato de um Mucker - "Então o senhor deve ser parente do fulano de tal". "Sou o bisneto dele, e queria dizer uma coisa. Agora, depois do seu livro, posso dizer para meus filhos que não precisam ter vergonha de ser descendente de um Mucker...”

Maria Amélia: Comigo aconteceu algo parecido...

Assis Brasil: Isto vai acontecer. E principalmente com o filme, que é um meio de difusão muito mais ampla.

Carlos Steil: Isto se aproxima um pouco do papel dos antropólogos na história que tem sido o de mostrar que os seus nativos não são tão irracionais... 
Assis Brasil: Ah, sim, claro, puderam fazer esta ponte.

Fábio Barreto: Esta coisa de falar da relação do episódio com o "hoje”. No Quatrilho também aconteceu. O "gringo" chegar lá e dizer "Hoje nós não temos mais vergonha de sermos chamados de 'gringo'. Antigamente a gente ficava chateado. Eu sou gringo com muito orgulho.” Como é que hoje, isto é interessante, até que ponto isto está vivo? O episódio dos Mucker está lá na região. Eu sinto assim uma defesa, uma simpatia da sua parte, quase fanática, como você defende ela. Eu acho fantástico. Justamente, sou um pouco assim, eu gosto muito da Jacobina, eu falei do jeito que falei, mas eu adoro ela. Tem uma senhora, lá, que percorreu a região com a gente, que é uma defensora ferrenha dela, uma coisa assim... porque tem pessoas na região, olha...

Maria Amélia: Agora. É recente.

Fábio Barreto: O quê?

Assis Brasil: Este tipo de atitude é nova...

Fábio Barreto: Ah, é? Esta senhora é lá da região. É do Museu Municipal. Ela adora... ela diz inclusive que parte dos sinais da pregação da Jacobina foram incorporados às cerimônias oficiais deles, religiosas, aos rituais, mas que nunca disseram. Pegaram coisas que a Jacobina falava e botaram no negócio deles e nunca ninguém assumiu. Você diz, os ataques dos outros, então, que influência têm? Porque tem associações que você pode [estabelecer] mas... havia, por exemplo, dizeres de gente que via ela [Jacobina] voar, levitar e tal... Hoje em dia tem gente que pula de asa delta do monte Ferrabrás. Faço estas analogias assim meio estapafúrdias, mas você entendeu? Por que esta vocação para o vôo?... [risos]... Porque aquilo... já cria uma expectativa mais para frente. Mas que ela vai levitar vai...

Assis Brasil: É, coloquei aquilo, usei o recurso do foco narrativo. Jacó Mula [personagem de Videiras de Cristal]; todos os episódios místicos são vistos por ele, por isso usei a terceira pessoa...

Fábio Barreto: Isto está mantido, porque é uma maneira de você não passar a acreditar como... verdade, não é? É ele que vê? Então, pronto. 
Assis Brasil: Por isso no livro, na cena inicial, ele faz um gesto curioso; o gesto de tentar imobilizar um passarinho botando sal na cauda. Isso já mostra a credulidade dele. Quando li uma parte do depoimento dele percebi que os outros depoentes disseram: "Olha, não dá para acreditar muito neste aí, porque este é meio bobo... ” Esse homem é que me interessa. Esse é o que vai ver tudo...

Fábio Barreto: Esta coisa da atualidade, é uma coisa que me interessa, que até hoje eu não tive tempo, mas eu vou passar um tempo ali, conversando com as pessoas que são contra e a favor, até hoje tem quem é contra e a favor. Outra coisa é, exatamente, que eu volto a cair numa mesma dificuldade que com certeza [existe] ao fazer um romance. Quando você veio, você trouxe para uma maneira, da coisa do sagrado e feminino, da coisa incestuosa. Que aí a gente vai às regras da dramaturgia clássica, tragédia grega, etc., entendeu? Como que você vai ter, poder identificar aquele personagem, como, e ter uma empatia com ele entendeu? Ele é ruim, ele é bom, ele é mau. Como é? Como a gente vai poder juntar este conflito? Em que nível está este conflito? Porque dramaturgia é isso: é conflito. Então, o que muitas vezes as pessoas ao lerem o livro ou lerem o roteiro dizem: olha, é uma personagem fascinante, mas eu não sei até que ponto posso gostar ou não gostar dela. Até que ponto posso ser a favor ou contra o que ela fez? Eu não sei até que ponto ela me é simpática, se eu sou simpático a ela ou não. Isto é muito difícil de trabalhar.

Maria Amélia: Quando tu falaste que eu a defendo com paixão... não é bem esta paixão que eu acho que estejas falando. A minha "defesa” é muito mais porque te vi reproduzir a "versão oficial”. E eu acho que isto é um perigo, porque a "versão oficial” simplifica. Simplifica a Jacobina como criminosa. Por isto eu te questionei. O que é crime? Crime é para os “outros” - quem está dizendo o que é crime? Crime é para a ordem institucional. Então, minha defesa de Jacobina é muito mais a defesa da possibilidade de múltiplas versões. E que eu acho que pode amenizar teu personagem...

Fábio Barreto: Certo...

Assis Brasil: ... só que o conflito perde em intensidade... 
Ana Luiza: E com relação à tua tese, Maria Amélia, como é trabalhar com este conflito dentro da escrita etnográfica. E no teu caso [Assis Brasil], como resolves este conflito que, creio eu, se processa de forma diferente, já que trabalhas com Literatura.

Maria Amélia: É, eu resolvo em uma tentativa de objetividade sobre os múltiplos discursos. Esta objetividade não é absoluta, não pode ser. Mas ela tem, diferente da literatura e do cinema, uma certa obrigação de estar mais colada ao evento. Eu estou relatando sobre o evento, eu tenho que estar o mais colada a ele possível. Aliás, eu queria fazer um parênteses e dizer (para Assis Brasil) que, durante a confecção da minha tese, não consegui ler Videiras de Cristal. Porque eu tinha muita raiva da tua liberdade (risos). Eu começava a ler e não conseguia... de repente eu me dei conta que era isto. Enquanto eu tinha que ficar presa ao que eles efetivamente tinham feito, efetivamente dito e tentar fazer sentido daquilo, tu podias dar asas a tua imaginação e acomodá-los todos à tua vontade [risos].

Assis Brasil: ... preencher os espaços...

Maria Amélia: Então, o que eu tentei fazer foi isto, não privilegiar nenhuma versão, mas conseguir dar conta das várias versões presentes. E, mais do que isto, pensar que as falas das pessoas, os discursos (que era o que eu tinha disponível porque eu não estava presente nos eventos, eu estava só com o registro escrito, não é?) elas, na verdade, diziam mais do que estava escrito. Eu tive a dificuldade de lidar com o material dos processos judiciais, discursos que estão inseridos numa forma absolutamente rígida, são manuscritos, com muitas falhas de transcrição, com muitas falhas nas grafias dos nomes alemães. ... até eu conseguir identificar todos os personagens... foi uma coisa muito difícil... Porque era necessário ir além dos discursos... eles me abriram uma perspectiva que foi a necessidade de lê-los num espaço onde eles estavam sendo produzidos. Quer dizer, eu tinha que conseguir entender este espaço onde eu não estava, onde não podia estar e que eu tinha que deduzir. Ao ler, tinha meio que "adivinhar" a partir das pistas que eram oferecidas pelos discursos dos personagens nos processos. Tive de tratar de perceber nestes discursos o mundo em que os personagens lutavam. O que eu tentei foi penetrar este mundo. Penetrálo através do texto escrito... É o limite do trabalho, não consigo resolver tudo... 
Fábio Barreto: Voltando a tocar nisso... a gente lendo sobre os Mucker, seu romance, sua tese, tudo... Já li tanta coisa a respeito, a gente sempre volta para uma coisa: a utopia positiva, não é? Da existência de um paraíso. Esta mulher vinha para nos dizer, "vai dar certo, nós vamos conseguir, vamos ser todos felizes, livres, vamos conseguir viver do jeito que a gente quer”. Até onde, por que esta coisa utópica, ideal, positiva, deu na desgraça que deu...

Assis Brasil: Normalmente terminam mal, em que pese esse discurso positivo. Essencialmente ele tem um discurso que encaminha a coisa para o melhor. E esse melhor está sempre muito além daquilo que é o possível. Por isso esse passar do possível. Sair da imanência para a transcendência, para usar um outro tipo de linguagem, é o que justamente atrai, que faz com que as pessoas participem. E como sempre há uma transgressão, quer dizer, este líder leva a uma transgressão. Transgressão política, legal, religiosa, enfim, moral e bons costumes... Acaba mal, acaba em tragédia. Como toda a tragédia, toda a tragédia é, justamente...

Fábio Barreto: ... precedida de uma coisa ideal...

Assis Brasil: Exatamente. Aí há a transgressão e há a punição. No caso, a gente pode pensar desde as tragédias coletivas até as tragédias individuais como Madame Bovary, por exemplo, rompeu o interdito e foi punida.

Maria Amélia: É, essa coisa também cristã da punição...

Daisy Barcellos: Tem algo que eu vejo e que está por trás de todas as reflexões, que a gente está fazendo. A delimitação do universo de análise e o foco da narrativa. Por enquanto, duas ou três vezes o Assis referiu a palavra episódio: o episódio dos Mucker. Este episódio dos Mucker, o fato Mucker, quer dizer, tendo um começo, um meio, um fim, reconstituindo este modelo bem universal de uma tragédia e que tem o potencial de ser centralizado num ator específico, ou no mínimo projetado neste indivíduo. Quer dizer, isto não é o que move e atualiza a Jacobina e os Mucker no contexto atual? Porque para a arte é excelente alguma coisa que possa ser delineada, para uma tese de doutorado, um fato delineado no tempo, delineado no espaço, com suas fronteiras mais ou menos demarcadas, em que tu possas, inclusive perceber essas trocas, como 
estão se dando. Não é o fato ideal, por tudo que suscita, e daí ser o que move? Além do fato do nosso imaginário o construir desse modo?

Assis Brasil: Mas eu uso a palavra episódio como faut de mieux porque realmente eu vou chamar de... não é guerra... não é revolta.

Daisy Barcellos: O não dito, o não respondido, o indizível, o incompreendido deste fato...

Assis Brasil: Pois é. Especialmente a questão da atualidade que tu falavas, não é? Está dentro daquela idéia das personalidades. Quer dizer, a atualidade, nós vivemos na nossa sociedade pós-moderna em função de personalidades. Aquela história dos 15 minutos de fama está ligado muito a esta questão. Até a gente vê as revistas culturais do nosso país, sabe, Bravo! Aplauso, esse tipo de coisa assim. Então não é por nada que, centrar numa figura, como o caso da Jacobina, é uma atitude muito contemporânea. Não sei se isso, na década de 60, quando a perspectiva era coletivista, pensando nas Humanidades de um modo geral, teria o mesmo enfoque. Acho que hoje, o enfoque é na personalidade.

Maria Amélia: Eu acho interessante tu falares isto. Tens toda razão de falar isto, porque quando eu comecei a trabalhar com os Mucker, e eu comecei a trabalhar com os Mucker, larguei os Mucker, voltei aos Mucker... mas quando eu comecei na década de 70, jamais me ocorreu pensar pelo ponto de vista de um feminismo, de uma teoria sobre a condição feminina, jamais. E acabou que quando finalmente retomei a sério para terminar o assunto, eu ainda estava muito presa, como minha tese mostra, a toda esta bagagem que eu trazia do início do meu contato com os Mucker. Só depois que eu fui poder pensar a questão dela [Jacobina] como indivíduo, dela como uma mulher...

Assis Brasil: Hoje nós já temos a liberdade intelectual. Isso que centra. Está dentro de uma visão bastante contemporânea...

Fábio Barreto: É, eu acho que isto que você falou que quando você, na sua infância, você ouvia falar de Mucker, tinha um Mucker por aí.

Assis Brasil: Era o "velho do saco”... 
Fábio Barreto: ... No final da tua tese teus Mucker ficaram vagando pelo meio do mato, vivendo ali. O próprio Jacó Mula ficou no meio do mato sete anos. Então, eu acho que o que é interessante, e que eu não tenho isso assim como uma coisa que se eternizou e até hoje está sendo investigado, estamos aqui falando e tal... Até que ponto a minha investigação se dá no nível de qual Mucker eu sou ou não, o quê de Jacobina eu tenho em mim ou não, sabe ? O que tem de Jacobina que eu quero, que eu gosto. Então, é isso aí que está... a dramaturgia propriamente dita, a história, o romance, um filme, vão ter um início, um meio e um fim, é claro. Mas aquilo que me interessa muito é isso, é sobretudo falar dessa outra parte de como, de qual Jacobina... milhares de mulheres se chamaram Jacobina. Lá na Inglaterra a galesa disse "Eu sou Jacobina”, quer dizer, muitas outras pessoas... Aí a gente vai também chegar à própria discussão da paranormalidade. A Jacobina era uma paranormal ou era uma doente, ou era uma sonâmbula, o que ela era? E os “poderes” dela? Até que ponto? Isto eu acho que pode ser tocado. E aí já cria um outro paradoxo que é o da ciência e o da religião, né?

Maria Amélia: Isto está colocado lá, está colocado no caso.

Fábio Barreto: Está.

Maria Amélia: Este paradoxo da ciência e da religião está colocado pelos discursos dos intelectuais.

Fábio Barreto: Está, o tempo todo.

Maria Amélia: É interessante reatualizar isto. Eu só queria voltar à questão da Daisy sobre o episódio, do começo, meio e fim que vocês estão se referindo. Porque para mim... não tem começo, meio e fim e uma das maiores dificuldades que eu tive na minha tese foi definir onde começar e onde terminar. Porque eu sabia que não tinha terminado onde terminei, não é? Sei que ainda não terminou, mas não tive acesso a onde ele ainda existe. Sei que ainda existe mas... bloquearam totalmente o acesso. É um mundo feminino, mas não me deixaram entrar porque eu não sou Mucker. Então, esta questão, não chamo de episódio por isto, porque para mim não é, mas acabas tendo que te definir num limite, né? 
Assis Brasil: É claro, isto é uma questão de técnica de romance.

Daisy Barcellos: Presta-se para delinear como uma totalidade, não é?

Assis Brasil: Só que nós temos que pensar que episódio é a parte de um todo, tecnicamente é parte de um todo. Tanto que a novela televisiva fala em episódio...

Maria Amélia: Outro problema que eu tive, ao lado do recorte temporal, digamos assim, foi o de eu ser uma antropóloga que tinha que trabalhar com documentos escritos, do século passado. A antropologia, hoje, se constrói sobre o trabalho de campo, do contato etnográfico, da vivência no campo. Trabalhando com documentos, e exclusivamente com eles, fui muito questionada pelos meus interlocutores da academia sobre não estar fazendo trabalho de campo "tradicional”. E até hoje sou questionada sobre isto. Eu não sou "antropóloga verdadeira” porque eu não fiz trabalho de campo. Precisei pensar em formas de demonstrar que era legítimo penetrar estes documentos com novas questões, mostrar afinal, que eles não são estáticos, não estão congelados, não estão mortos, eles são passíveis de uma leitura que extrapola seus aparentes limites como informação etnográfica. Tive que fazer, inclusive, uma longa introdução justificando e explicando minha postura. Tentei fazer, com os documentos, aquilo que mencionei há pouco, sobre penetrar nos mundos que eles podiam revelar. Não foi fácil para mim lidar com o que era um “episódio”, com começo, meio e fim aparentemente definido e distante. O processo de aproximação foi árduo, muito doloroso, até, mas por outro lado, muito revelador, muito instigante para as possibilidades deste tipo de trabalho.

Fábio Barreto: Você acha então que há mais ainda a se revelar? Que existe coisas ocultas, que você foi barrada...

Maria Amélia: Tem.

Assis Brasil: Tem arquivos...

Maria Amélia: Eu pedi e me disseram não. Eu pedi para ter acesso a uma coisa que eu sabia que estava acontecendo e que existia e disseram não. 
Fábio Barreto: Sei... Olha que interessante...

Maria Amélia: Eu queria voltar sobre o impacto do teu trabalho sobre as pessoas descendentes dos Mucker. Eu tenho uma experiência muito interessante em que uma pessoa com quem eu conversei muito durante a tese, que ajudou muito, convivemos o tempo todo, eu sabia que ela era uma descendente de Mucker mas ela nunca falou disso. Nunca disse para mim. Eu soube pela redes dentro das quais eu me movimento. Depois que ela leu minha tese, e eu estava na ocasião apresentando a tese publicamente, ela se levantou e me disse, depois do elogio e tal, que era descendente de Mucker. Ela nomeou a família, ela disse de onde vinha e disse que um dos grandes valores da minha tese era ter resgatado a honra de muitas famílias. Me pareceu uma coisa muito forte! Então, imagino que seja uma coisa muito viva, é ainda uma coisa muito viva. Essa pessoa é bisneta de Mucker e que ainda sente esta carga como carga pesada.

Assis Brasil: Um dia, um descendente fez um trabalho sobre a Jacobina.

Fábio Barreto: Outro dia teve um evento em Novo Hamburgo, e tem não é? Vieram se apresentar para mim, o cara era Mentz e ela era Maurer. Eles eram casados. E donos de uma rede de lojas, de uma rede de lojas. Todos os dois descendentes e muito felizes, dizendo que são descendentes da Jacobina e do João Jorge.

Maria Amélia: Eu acho interessante, sabe o quê? Que tu vais ter mais acesso a este tipo de manifestação que qualquer um de nós por causa do que tu estás fazendo com a história: o cinema apela às pessoas.

Assis Brasil: Um público muito maior...

Carlos Steil: Eu queria levantar uma outra questão nesta conversa, que tem a ver com a preocupação da antropologia: a questão do autor. Já se falou, inclusive, que em todos esses campos trata-se sempre de interpretações. Você fala da Jacobina, assim como o Assis Brasil a partir de contextos diferentes. Mas como pensar a questão da verdade nestes contextos: no da antropologia e no da literatura. Com certeza esta questão não se apresenta da mesma forma para a 
literatura, para o cinema, como se apresenta para a antropologia, que vive um paradoxo de ter que falar cientificamente a partir da subjetividade, a partir da experiência subjetiva. Uma questão que tem a ver com o que a Maria Amélia estava levantando aqui, sobre as dificuldades dela se apresentar como antropóloga visto que ela não estava lá, que ela não viu, não assistiu. Porque este, acho, que é o grande paradoxo da antropologia, que tem que provar a verdade através da subjetividade o que é sempre muito complicado. Então, eu queria colocar esta questão para vocês três. O que é ser autor? O ser autor no romance de ficção, o que é ser autor de um roteiro de filme que se baseia num livro, quem é o autor? Por fim, o que é ser autor no caso de uma tese como esta da Maria Amélia, que falava a pouco da sua inveja em relação à liberdade do autor propriamente de ficção.

Assis Brasil: A gente tem que pensar que a palavra autor tem o mesmo radical de autoridade - auctor... São palavras que têm a mesma raiz, o mesmo espírito, o mesmo conteúdo semântico. É condição do trabalho do autor essa autoridade, no sentido do criador de um universo. Quer dizer, o universo criado pelo autor é um universo verdadeiro, é aquele universo. Isso explica a existência dos contos de fadas, da ficção científica. Mas o autor, quanto mais autoridade ele tem, no sentido da criação do seu universo, mais ele deve ser fiel a ele mesmo, porque na construção da narrativa existe o princípio de causa e efeito que existe no mundo natural. Então, desde que eu estabeleça uma causa e faça decorrer daí um efeito, tenho de ser fiel a esta mesma dinâmica, de tal maneira que eu forme um universo que se explique por si mesmo. É a relação de causa e efeito se tornando obrigatória. E esse autor acaba se tornando um escravo da sua própria autoridade. Quer dizer, ele cria determinadas premissas e tem de ser absolutamente fiel a elas.

Fábio Barreto: É, o senhor falou da verdade interna, é fundamental ser fiel a ela. A Jacobina, que é uma mulher que existiu, aí vocês a trazem como uma obra de ficção, livro, filme. Mas ela tem que ter uma verdade, você tem que atribuir a ela uma verdade interna. Se ela fala que o mundo vai acabar, o mundo tem que acabar. Só que todo mundo sabe que o mundo não acabou, não é? Ela pode acabar por nascer uma outra coisa, entendeu? Então, a interpretação, no caso, eu acho que o autor existe para dar possibilidades, abrir possibilidades para múltiplas interpretações. É lógico, a gente sempre tem uma... nós temos, e 
é difícil se abster de julgar, no caso só de expor, e que eu como autor é o que tento fazer. Expor, dar vazão ao máximo do que eu puder produzir, inconscientemente até, porque tem uma produção inconsciente muito forte. E que, sendo inconsciente, eu estou praticando ela [a interpretação] sem saber. Às vezes eu vou ver isto com o filme passando para o público, através das reações dele. Coisas a que o público reage e que eu absolutamente não programei, entendeu? É quase como me conhecer através de uma multidão (risos). Então eu acho que o autor, a base da sua posição, do seu reconhecimento é o criar e experimentar.

Isabel Carvalho: Tem um drama aí que é o drama do narrador, que a gente encontrou tudou em Paul Ricoeur. Quando ele traz a dimensão da intriga, tecer a intriga. E é nisto que constitui fazer uma narrativa. E qual era o drama da tecitura da intriga? Paul Ricoeur vai resgatar qual o balanço entre duas ordens de coisas, a abertura e o arbitrário do destino e, ao mesmo tempo, o encadeamento significativo dos fatos de modo que no final você diga, ah, tudo aquilo levava a isto. Ou seja, injetar um fio de sentido e, ao mesmo tempo, recuperar um episódio, um evento da vida que tem este arbitrário e esta aventura do destino.

Fábio Barreto: É que você está falando na intriga, na trama no caso, a narrativa. Então, quer dizer, no clássico você tem uma narrativa horizontal que vem da tragédia. Depois, o próprio drama fundamental, é o conflito... No clássico, você narra. $\mathrm{O}$ autor, ele vai escolher. $\mathrm{O}$ que ele vai privilegiar, a narrativa ou os personagens? Porque você pode colocar os personagens na cena narrativa, você pode abdicar da trama ou da intriga como você está falando, e privilegiar o comportamento dos personagens.

Assis Brasil: ... há o chamado romance de personagens.

Fábio Barreto: Exatamente, ou filme de personagens. Filmes de comportamento, não é? No clássico você tem aquela trama, se tem o herói, o vilão, o protagonista, o antagonista, não é? Que vai horizontalmente narrando... Tem um filme que está passando, inclusive muito bom, que entrou agora, se chama O Gladiador, que é isso: o herói, como ele entra numa crise, porque crise é crescer, quer dizer, vai ao fundo do poço, fica fraco, se humaniza, todo mundo 
se identifica, na crise é onde ele vai buscar forças. Onde ele vai se conhecer mais, onde ele vai buscar forças onde ele jamais soube que teve. Aí ele supera a crise, volta e acaba com o "filho da puta" e fica todo mundo feliz. Na crise, esta narrativa não avança, ela é vertical, ela vai lá na crise do herói. Só vai voltar a avançar, a ser horizontal, quando a crise acabar e aí vai pegar o vilão e acabar com o vilão.

Assis Brasil: Fico pensando no caso da Jacobina em especial... quem escreve o romance está envolvido com seu próprio mistério, com suas próprias fantasias... Já o filme tem muito de coletivo, algo muito íntimo compartilhado com dezenas de pessoas. Acho isso absolutamente diabólico. Eu não teria menor capacidade de me encontrar ali, naquele meio; enfim, ser autor: porque tem a iluminação, a produção, porque tem, sabe, aquele mundo de coisas... por exemplo aquele mundo de coisas em volta de um casal que está se beijando, aquela coisa íntima que a gente descreve assim quase se escondendo da gente próprio.

Fábio Barreto: Aparentemente para quem vê assim, parece profanação da criação do autor. Mas não é, muito pelo contrário, você está protegendo aquilo tudo, você está pegando aquele ritual, num primeiro momento você está profanando, você está invadindo, você está violentando, mas para quê exatamente? Para fazer com que ele seja mais rigoroso, mais intenso, mais denso, se tem a ver esta primeira profanação...

Assis Brasil: ... mas aquele monte de gente!

Maria Amélia: Eu estou mais perto do cineasta, que engraçado. Porque o tempo todo em que estava fazendo o meu trabalho, as milhões de pessoas estavam falando comigo, não é? Meus colegas antropólogos, os autores que eu tinha que ler. Ou seja, eu estava tendo que dar conta de um universo ... que me dava muito pouco tempo para intimidade. Os momentos de intimidade foram aqueles em que eu pude, que eu tive tempo, tentar burilar um pouco o linguajar, me apropriar melhor dos termos. Mas não tem esta dimensão do romance de forma nenhuma.

Fábio Barreto: A tese é diferente... 
Maria Amélia: E também, eu acho que... bom não sei como vocês reagem e pensam sobre a crítica, mas ao fazer uma tese, você está sempre pensando as formas pelas quais ela pode ser contestada, tratando de prevenir que ela seja contestada por aquelas formas que você pode prever.

Fábio Barreto: O ideal para uma tese é que não seja contestada?

Maria Amélia: Não. Não que ela não seja contestada, mas para ser bem contestada tem que ser bem construída. E isto é o complicado da história. Então, na verdade eu me senti muito cheia de companhia o tempo todo em que eu escrevi, o que era pesado... apesar de gostar muito de escrever. É uma prática muito prazerosa.

Assis Brasil: É uma prática muito apoiada...

Maria Amélia: Sem dúvida, acho que isto é fundamental.

Assis Brasil: Acho que até na escolha do que vai, do que não vai, só ali já existe criação.

Fábio Barreto: Uma tese é também uma criação.

Assis Brasil: ... e, depois, uma interpretação.

Ana Luiza: É uma coisa interessante o que ela [Maria Amélia] falou, ou seja, trabalhar com "arquivos" é dar vida àquilo que de alguma forma é "letra morta”. Não estamos aqui um pouco próximos da literatura, isto é: dar vida a um personagem. Quer dizer, ler a tua tese é, de alguma maneira, ver aquelas pessoas agindo e pensando a partir do contexto em que viviam. Então, acredito que isto está muito próximo do ato de conservar a vida dos acontecimentos passados, não é?

Carlos Steil: É tirá-los da morte...

Ana Luiza: A figura do narrador na pessoa do antropólogo... Isto é interessante e, ao mesmo tempo, um processo difícil de ser realizado, não? 
Maria Amélia: Muito difícil por causa desta preocupação com a objetividade, com a interferência da subjetividade, é claro... então é uma luta constante.

Daisy Barcellos: E depois, situar as múltiplas versões enquanto versões, porque aqueles depoimentos com os quais tu trabalhas, e fazes isso muito bem, permitem "enxergar" aqueles colonos depondo nas delegacias. Eu creio que tu fizeste isto muito bem. E isto já são versões. E tu buscas uma objetividade ali, não é?

Carlos Steil: O Assis Brasil também trabalhou com toda a literatura dos processos...

Assis Brasil: Sim, claro, usei o que me interessou...

Maria Amélia: Mas tu leste todos os processos que estão no Arquivo Público ou só os do Histórico?

Assis Brasil: No Histórico. Como eu dizia para os amigos aqui, antes. Parodiando o Mário Quintana, o ser escritor é agravante e atenuante ao mesmo tempo. Quer dizer: a gente toma liberdades que, por outro lado, também são permissíveis... enfim: o melhor é esquecer tudo e tentar fazer um bom romance. Antes de mais nada, tem que ser um bom romance, que apaixone. Não faz mal que diga que Dom João VI proclamou a independência do Brasil. Importa é que seja bom. Hoje essas fronteiras entre o histórico e o ficcional estão completamente derruídas...

Carlos Steil: Então, como é que tu inseres a história no romance escrito? Tu que trabalhas com uma literatura chamada realista e com o romance histórico?

Assis Brasil: Toda história é uma versão da História. Meu romance é uma versão. Temos, no romance, uma realidade de papel, que é o papel da História. Não temos confiança nos documentos, pois eles são uma versão a mais. Se a gente tomar algumas investigações que estão sendo feitas hoje e ler estes documentos, são versões diferentes. Acho muito interessante o trabalho do historiador: ele gasta tempo e suor para construir uma verdade, que no fim é uma verdade fictícia. Então, digamos que o romance é uma versão a mais, tenta ser 
uma versão mais agradável, tenta ser. Porque o escritor, por princípio, deve ter o domínio da linguagem literária, quer dizer, tornar a coisa mais interessante, mais rica, mais sedutora; mas sempre será uma verdade de papel. O que importa é que seja coerente.

Fábio Barreto: O que você falou, que a antropologia puxa uma verdade subjetiva. Eu diria que, quer dizer, eu não acredito em nenhuma verdade... a antropologia busca esta verdade pela subjetividade e, no caso que eu faço, não tem que afirmar nem negar nenhuma verdade, é expor. Existem possibilidades na verdade, não tem uma verdade. Eu lido com possibilidade e não com "uma verdade”. Eu acho que fazer um filme sobre este assunto, sobre a Jacobina, eu de antemão quando li o próprio romance, o Assis Brasil é a favor dela, não é? (risos) Porque é um personagem fascinante que a gente fica, a gente gostaria que existissem mais Jacobinas. Gostaríamos de encontrar Jacobinas por aí hoje... Oi Jacobina!

Daisy Barcellos: Só nome dela eu já acho fascinante...

Fábio Barreto: Eu não vou poder, então, está sendo muito difícil para mim, porque quando você vai lidar com um material como este, personagens como estes, não é? Você expor, colocar aí, tudo. Acho que todas as possibilidades, não são as verdades, as possibilidades... É bom, é mau, é ruim, é isto, sabe? Foi assim... não foi assim, sabe? Você dá subsídios a quem for assistir para poder julgar como melhor lhe convier, de acordo com a sua consciência. É muito difícil.

Ana Luiza: Mas o que isto que acabaste de falar remete aos mitos que cercam a imagem do homem brasileiro. Tu falaste aí da cordialidade, não é? O que cada um de vocês retira da história dos Mucker e da personagem da Jacobina para pensar o Brasil?

Carlos Steil: Talvez se possa pensar na relação da parte e do todo, do regional e do nacional.

Ana Luiza: Tem também esta coisa do Bem e do Mal... O que se assiste é uma intolerância em vários aspectos, na questão da mulher, da religião, da etnia... Eu fico pensando se não é o personagem da Jacobina que nos expõe estes 
temas sobre o Brasil, isto é, coisas que são mais difíceis de serem assimiladas pela sociedade brasileira, não é?

Assis Brasil: É, ainda mais no caso. A coisa sempre foi sentida pelos brasileiros como um fenômeno "alemão", tanto que até em Estrela eles falavam "os brasileiros"... e eu uso no meu romance em itálico - os brasileiros. O próprio bispo disse para Mathias, "isto é um problema dos alemães”. O presidente da Província também disse que este era um problema "dos alemães”.

Daisy Barcellos: Isto até se coloca em questão na tua tese, quando tu apontas a própria política imigrantista ...

Assis Brasil: Claro que tinha a intenção branqueadora, mas parece que só agora está dando certo...

Maria Amélia: Existem documentos no Congresso Nacional, que na época não se chamava assim, com transcrições de sessões dedicadas a este caso. Foi tratado também na esfera do Império. Nas transcrições há opiniões contrárias: alguém que opina pela intervenção, o quanto antes, das forças imperiais, a maioria dos deputados dizendo que, absolutamente, que o problema é uma coisa dos imigrantes... aqueles camponeses... assumindo que eles tinham desenvolvido um aparato institucional como que “interno” à etnia, digamos.

Assis Brasil: Eles, que têm suas autoridades...

Fábio Barreto: Eu acho que tem a ver com a brasilidade na medida em que, Jacobina tinha essa coisa da utopia positiva, "vai dar certo, nós vamos conseguir - isso é brasileiro”, eu acho que isso é brasileiro, tem algo de brasileiro aí. Nem tanto...

Maria Amélia: Eu acho que isto da "utopia positiva” é algo que os brasileiros podem reconhecer, mas ela não é brasileira...

Daisy Barcellos: Pode ser da utopia imigrante, não pode?

Maria Amélia: É verdade! 
Carlos Steil: Assis Brasil, você que tem experiência como escritor poderia falar um pouco sobre a recepção do teu romance fora do Rio Grande do Sul? Como é que as pessoas de fora do Rio Grande receberam o teu romance? Ou seja, como é que o Brasil pode sentir esse acontecimento dos Mucker hoje? Pode, através do cinema ser sentido como um episódio nacional? Acho que $O$ Quatrilho conseguiu isso, em grande parte. Com o “O Quatrilho” de repente o Brasil se reconheceu no Rio Grande do Sul na medida que os brasileiros se identificaram com o Quatrilho e com a imigração italiana. Como compreender essa relação entre a parte e o todo, entre o regionalismo e o nacionalismo? Talvez o Assis Brasil pudesse falar um pouco mais sobre a repercussão nacional, ou mesmo internacional de um fato local. Afinal, o filme quer ser não só nacional mas universal, tem que ganhar o Oscar. Como é que tu vês isso?

Assis Brasil: Aqui estão duas questões, que pedem uma resposta dupla. Acho que há, em primeiro lugar, o conhecimento do episódio. Todos querem saber como aconteceu. É muito natural que as pessoas queiram saber. Há, por outro lado, a valorização de uma colonização específica. Assim, duas questões: o acontecimento em si e o trazer à tona uma colonização que enfim, é bem pouco falada relativamente, por exemplo, à colonização italiana. Este é o caso especialmente, de $O$ Quatrilho, que revelou um outro italiano que o Brasil não conhecia. O Brasil conhecia apenas o imigrante do século XX, mas não o imigrante do século XIX. Então o filme terá também, essa dimensão esclarecedora... quer dizer, vai ser o contar esse episódio que é muito intrigante, muito interessante e, por outro lado, também de trazer um reconhecimento... O que existe em relação ao livro ... são feitas analogias com Canudos, e não há crítico que não tenha falado sobre o livro que não tenha relacionado a Canudos. Tanto que essa dissertação dessa menina daqui do rio Grande do Sul (Cláudia Mentz Martins), que defendeu sua dissertação na PUCRS no ano passado, fez essa relação e eu sei de dois outros trabalhos acadêmicos fazendo essa ligação. O "nacional” do episódio entrou da metade para o fim, com uma repressão armada, e essa é uma questão bem importante, porque nós, nós... vamos dizer, “os brasileiros”, participamos desse episódio com o que sobrou da Guerra do Paraguai; o exército brasileiro não tinha mais nada em armamento; o capitão Santiago Dantas conseguiu formar quatro canhões, juntando uma peça de um, uma peça de outro, para vir para cá. 
Fábio Barreto: Na verdade, os Mucker, eles deram a dimensão do que era o exército brasileiro naquela época.

Assis Brasil: Especialmente depois da guerra do Paraguai. Foi o que o exército possuía. Aliás, haviam recebido como amostra aqueles foguetes incendiários, chamados de a congreve, que possuem uma rampa de lançamento. Era moderníssimo. O resto, dois morteiros que tinham, quebraram...

Maria Amélia:... e os canhões também!

Assis Brasil: E os canhões também. É impressionante. É um testemunho que liga o episódio dos Mucker à Guerra do Paraguai.

Fábio Barreto: Não, mas eu acho que tem a ver também com... eu acho que o episódio dos Mucker, ele teve uma influência. Quer dizer, a colonização alemã estava já quase há cinqüenta anos quando isso [o evento Mucker] aconteceu, e teve uma influência fundamental em como ela iria se desenvolver dali para frente. Se ela ia se estratificar, quer dizer, se ela ia ter uma parte pobre e uma parte... [rica] ou se ela ia caminhar junto. Eu acho que o ... Mucker foi fundamental porque, não é? Que houvesse até uma unificação de objetivos, de propósitos... a prosperidade propriamente dita, a distribuição dessa prosperidade.

Assis Brasil: Até porque os Mucker deram um passado mítico à colonização alemã. Os colonos não tinham esse passado. Passaram a ter.

Maria Amélia: Infelizmente um mito negativo, mas um mito que possibilitou construir toda a positividade posteriormente. "Nós não somos aquilo, aquilo aconteceu, mas não é o que nós somos, nós somos o outro, nós somos o alemão do trabalho, não o da crendice...”

Assis Brasil: E estamos justamente nesse momento de mudança de perspectiva em relação aos Mucker.

Carlos Steil: Essa questão é muito interessante porque até o fato de ter terminado, pode ser repensado... "nós não somos isso", porque tudo que tínhamos de ruim terminou com os Mucker. 
Maria Amélia: O livro do Petry é muito isso. O livro do Leopoldo Petry que se chama $O$ Episódio dos Mucker, ou seja, já acabou. É um livro que nega o tempo todo a validade de ser alemão daquele jeito. Não! Ser alemão é outra coisa.

Carlos Steil: O romance, a tese, o filme podem permitir uma reinterpretação, e reassimilação dos Mucker.

Daisy Barcellos: ... e continuar ocupando um lugar nessa identidade positiva.

Assis Brasil: Mas é importantíssima essa tragédia na História, esse mito... todos os povos têm uma tragédia. Assim como a Grécia tem a Guerra de Tróia. A meu ver, a constituição desse mito é muito importante, até por um processo dialético, como justamente falavas. Quando se anda pelo Ferrabraz - Sapiranga -, vêem-se lojas, estabelecimentos “Klein”, por exemplo. A gente olha as placas lá, são todas, quer dizer, é um processo de reversão. O episódio Mucker vai ser entendido como mito fundador. O mito fundador quase sempre uma tragédia, e muitas vezes essa tragédia é um parricídio, é um matricídio, é uma transgressão, mas é uma tragédia. Esse caso Mucker é importante por isso, porque todo o mito fundador revela uma transcendência.

Carlos Steil: ... mas outra coisa sobre a qual eu gostaria que tu falasses um pouco, é do papel da psicanálise no teu romance. Videiras de Cristal começa com esse simpático psiquiatra que surge, no século XIX, antes mesmo de Freud.

Assis Brasil: É, estudei isso. Na época a personagem era estudante da psiquiatria.

Isabel: Uma pré-história da psicanálise?

Assis Brasil: É isso! No inicio, o Charcot... Inclusive ele é citado nos livros da época. Quer dizer, ele era um homem assim do seu tempo, que estava "up to date” com as conquistas da psiquiatria.

Carlos Steil: Na perspectiva do mito, do parricídio como fundadador da civilização na abordagem psicanalítica, qual a relação com episódio dos Mucker e a questão da transgressão. 
Fábio Barreto: É que as mudanças ocorrem em todas as direções, as revoluções... né!

Assis Brasil: E as culturas se fundam em tragédias. Reais ou verdadeiras... mas se fundam.

Fábio Barreto: É, esse personagem do Fisher é muito importante, o Fisher é um cara "relaxado" [em oposição a tenso], que não é ficção. Você disse que ele existiu, mas você criou ele todo.

Assis Brasil: Não, claro! Eu sabia que ele existia, que era médico. Valesca, minha mulher, tem um retrato dele quando ele fez cem anos. E descobri mais coisas dele; fui atrás, recuperei documentos, coisas muito interessantes. Era um homem interessante... mas claro, ele teve de ser recriado, todo mundo sabe! Ele tinha um nome, uma profissão, um defeito físico (mancava de uma perna, e isso o fazia usar uma bengala, desde jovem). Ao saber desses detalhes "reais", eu disse: "Bom, não preciso de mais nada... a personagem está pronta". Na verdade, Christian Fischer é um truque de ficcionista, pois ele é o olho exterior, necessário. Quero dizer: ele é o olho que organiza, que entende, que faz ilações, que estabelece comparações, que dá o salto interpretativo. Há uma outra moça que fez uma dissertação de mestrado na PUCRS no ano passado (Isabel Cristina Farias de Lima) em que estudou a figura do médico na literatura, especialmente na literatura do Rio Grande do Sul. Um deles é o Dr. Winter, de $O$ Tempo e o Vento, que é também um alemão; a outra foi uma personagem do meu primeiro romance (Um Quarto de Légua em Quadro), também médico, que possuía uma visão externa de um outro fato, que foi o povoamento açoriano no Rio Grande do Sul, aliás, outra tragédia. Quase sempre que acontece esse olhar exterior, ele é o de um médico. Não só na Literatura daqui do Rio Grande do Sul, em outras literaturas. Isso foi algo que fui descobrindo depois. Claro que o Dr. Winter estava na minha cabeça, mas no momento em que escrevi eu não pensei conscientemente. Mas eu precisava dessa visão externa, se não eu iria cair numa espiral sem saída.

Maria Amélia: Eu queria falar de subjetivismo, e de um personagem masculino, já que estamos falando de homens do teu romance. É o Mathias Münsch, o padre que "vira”, que "troca de camiseta" [muda de posição perante os fatos]. 
E eu fico me perguntando por que ele "troca de camiseta", não entendi muito bem por que,... não consegui entender por que e fiquei pensando... trazendo a psicanálise ... quanto de culpa ele não tinha nessa história, e que culpas eram essas que estavam ali?

Assis Brasil: Mathias Münsch, para ser missionário, me fez recuperar toda história da Companhia de Jesus e, e junto, de seus missionários (sendo eu exaluno jesuíta essas coisas são familiares para mim). Recuperei tudo isso. Ele, o padre, esperava encontrar uma dada realidade e encontrou outra completamente diferente; a partir daí, reavaliou as suas perspectivas. Aquilo que imaginava chocou-se com o que viu: a barbárie - que foi, na verdade, o resultado de uma repressão. Claro, quem pode dizer o que é o livro é o leitor, o escritor é uma opinião a mais. Mas eu não quis fazê-lo como alguém que tivesse culpa, totalmente. Ele é uma pessoa que morre antes de chegar a uma conclusão, a uma decisão. Achei que isso poderia dramaticamente render bem.

Maria Amélia: É, mas numa análise fria, sabendo qual foi a história dos jesuítas em relação aos Mucker, que foi absolutamente diferente da dele... bem, eu fiquei me perguntando... quando eu finalmente consegui ler o livro (sorriso!), minha sensação primeira foi a de que Christian Fischer, era o personagem através do qual o autor se conduzia pela narrativa. Mas, nas outras leituras posteriores quanto mais eu "mastigava” o livro, fiquei me perguntando o quanto de Assis Brasil não estava em Mathias Münsch... e expressando toda a relação complicada dele com o “episódio”, com ambigüidade da Jacobina, o teu dilema com o caso, a tua ambigüidade em relação a ele não foi expresso ali, no Mathias Münsch?

Assis Brasil: Concordo. Repeti essa mesma conduta no livro que publiquei em 1997, Breviário das Terras do Brasil. É minha formação jesuítica que leva a isso. Quando saiu o livro, um crítico lá do Rio disse “... mas é inexplicável a ardorosa apologia que tu fazes dos jesuítas na Inquisição”. Aí é que está: se o autor se joga em alguma personagem, ele tem de se permitir ser essa personagem.

Carlos Steil: Ao te ouvir sobre a criação dos teus personagens não posso deixar de fazer uma relação com a antropologia. Acho que nós também, como 
antropólogos, projetamos um pouco de nós mesmos na escolha dos informantes. Ou seja, como estavas dizendo ao mesmo tempo em que a gente escolhe, também projeta um pouco da experiência pessoal, da subjetividade, nas personagens assim como nos informantes.

Assis Brasil: ... não em todas as personagens, mas em algumas.

Maria Amélia: Sobre o que tu tinhas colocado da possibilidade de cruzar fronteiras para além do Rio Grande do Sul, para além da fronteira do estado: eu acho que vai poder cruzar através dos universais representados. Mas fico pensando na tua dificuldade de conseguir colocar isto numa linguagem que seja passível de compreensão. A imigração italiana já é "brasileira” ... é muito veiculada por TV, todo mundo imita o "sotaque italiano", todo mundo "sabe tudo" sobre ela. Mas o alemão e, por decorrência, a imigração alemã, aparece como uma coisa dura, chata... é um estereótipo também, claro. Mas lidar com este estereótipo num veículo de mensagens em que o visual e o auditivo são tão importantes juntos... penso que será difícil...

Fábio Barreto: Até pelo fato de ser germânico... O país é um país latino, o alemão é anglo-saxão, já tem uma distância maior, é mais difícil de você atingir.

Maria Amélia: Eu acho que vai ser uma tarefa extremamente árdua e que graças à Deus (risos) eu não tenho esta responsabilidade. A “viagem” do meu trabalho passa por outras questões.

Fábio Barreto: Não..., mas eu acho que vai dar... dá sim.

Maria Amélia: Não, eu acho que vai, eu estou achando fantástico que você tenha topado o desafio, eu acho que é realmente um desafio grande. Se você não banaliza a especificidade, para não deixar de ser específico, e conseguir tratar...

Assis Brasil: ... e fazer um espetáculo...

Maria Amélia: É! 
Isabel Carvalho: É aí que está a originalidade. Porque com os italianos você já tem até muito mais coisas.

Fábio Barreto: Já tinha um antecedente, que agora está muito mais aberto e tal. Mas isso aí, tem a coisa da cultura, mas tem as personagens, as personagens... elas transcendem a cultura, vão além...

Daisy Barcellos: Elas é que falam, não?

Fábio Barreto: Exatamente! 